\title{
Integrated Biomonitoring of Dioxin-like Compounds for Waste Management and Environment
}

\author{
Shin-ichi SAKAI* and Hidetaka TAKIGAMI \\ National Institute for Environmental Studies, Research Center for Material Cycles and Waste Management, \\ Onogawa 16-2, Tsukuba, Ibaraki 305-8506, Japan
}

Received April 17, 2003 and accepted May 6, 2003

\begin{abstract}
Many of the biological and toxic responses of polychlorinated dioxins and furans (PCDD/ Fs) have been shown to be mediated through the aryl hydrocarbon receptor (AhR). Several bioanalytical methods have been developed to analyze $\mathrm{Ah}$ receptor agonists in cost-and-time effective way such as CALUX-bioassay (chemical-activated luciferase gene expression). This bioassay can detect the sum of dioxin-like activity (including unknown substances) in complex waste and environmental samples. The present paper gives a description of the bioanalytical method and application examples to analyze dioxin-like compounds in waste management samples of thermal/ chemical dechlorination processes. The current detection limit of the CALUX in rat hepatoma H4IIE recombinant cells is less than $1 \mathrm{pM}$ TEQ $(0.06 \mathrm{pg}$ TEQ/well). The CALUX bioassay is considered to be useful tools for the rapid and integrated monitoring of environmental emission and residual samples as a pre-screening or in combination to chemical analysis.
\end{abstract}

Key words: Dioxin, Bioassay, Ah receptor, CALUX, Waste management, Incineration fly ash, Thermal dechlorination, PCB, Chemical treatment

\section{Introduction}

Dioxin-like compounds such as PCDD/Fs and PCBs show similar properties and display a wide variety of toxic effects in mammals, birds and fishes. Among the toxic effects observed as a result of exposure are immunotoxicity, carcinogenicity, metabolic changes, endocrine disruption and even death ${ }^{1)}$. The mechanism of action has been extensively studied over the past decades. The binding to the Ah receptor offers the biochemical analyst now several new technologies to analyse the dioxin-like activity of these compounds quantitatively (e.g. in vitro luciferase assays). The total sum of toxic equivalents (TEQ) of all kind of dioxin-like compounds can be measured. These new technologies have

*To whom correspondence should be addressed. been used already in several screening and biomonitoring programmes. Advantages are the extremely high sensitivity, rapid, easy clean-up/work-up, small sample size and reduced cost compared to instrumental methods. They have been already applied on a wide variety of matrices such as pure chemicals, food/feed and environmental samples.

Dioxin-like compounds have two types of their origin. PCBs have been intentionally manufactured and PCDD/Fs have been occurred as unwanted by-products in chemicals or formed in thermal processes. These persistent toxic substances (PTS) are now found in all kind of reservoirs e.g. contaminated landfills, sediments/soils and tend to be accumulated in biota. Therefore, PTS destruction processes have been developed as fly ash dechlorination and waste PCB destruction. This paper covered CALUX bioassay protocol, relative responses of dioxin-like compounds and some applications of biomonitoring during PTS destruction processes. 


\section{CALUX Bioassay Protocol and Relative Responses (REPs) of PCDD/Fs and PCBs}

The EROD (7-ethoxyresorufin $O$-deethylase) activity, which is one function of the cytochrome P-450 monooxygenase enzyme has been widely used for the detection of PHAHs (polyhalogenated aromatic hydrocarbons) in environmental samples. Because EROD can measure the catalytic activity (conversion of 7 ethoxyresorufin to resorufin) of the CYP1A1 isozyme induction which is the most prominent pathway through the aryl hydrocarbon receptor (AhR)-gene battery system. Also EROD activity can be measured both in vivo and in vitro. In vivo EROD assay has been conducted as a biomarker of exposure to PHAHs. Liver microsome containing CYP1A1 is extracted from animals such as rat, mouse, fish and wild bird, and their EROD activity can be measured ${ }^{2-8)}$. In vitro micro-EROD assays have been simplified using culture cells such as H4IIE rat hepatoma cell line, mouse Hepa lclc7 cell line, the PLHC-1 fish hepatoma cell line, rainbow trout liver cell line RTL-W1 and human hepatoma HepG2 cells in 96well microplates for the purpose more related to analysis of PHAHs $^{9-19)}$. For in vitro assay, induction of EROD activity caused by test samples can be compared with the induction curve of TCDD standard to determine biological TEQ (EROD-TEQ) values in samples.

EROD bioassay, however, has the following drawbacks ${ }^{20-22)}$ : -in vivo seasonal-, sex-, age-, diet-dependent fluctuations in induction

- low enzyme stability after death of animal (in vivo)

—in vitro substrate inhibition at greater ligand concentrations —in vitro long exposure time (requires $72 \mathrm{~h}$ for obtaining sufficient induction)

To circumvent the shortcomings of in vitro EROD, CALUX assay has been successfully developed based on AhR-mediated firefly (Photinus pyralis) luciferase gene expression $^{22-26)}$. A vector containing the luciferase gene under transcriptional control of DREs (dioxin responsive element) isolated from the 5'-flanking region of the mouse P450 1A1 gene, was stably transfected into hepatoma cell lines, including mouse (Hepalclc7) and rat (H4IIE) cell lines. The increase of luciferase activity is dependent on exposed TCDD concentration and comparable to that of the endogenous CYP1A1 activity. The primary improvement of the CALUX assay compared to the EROD assay is that increase of chemical concentrations do not cause decrease in the response of luciferase activity. Additionally, assay sensitivity to TCDD could be further improved compared to EROD, that is the current detection limit of the CALUX in rat hepatoma H4IIE

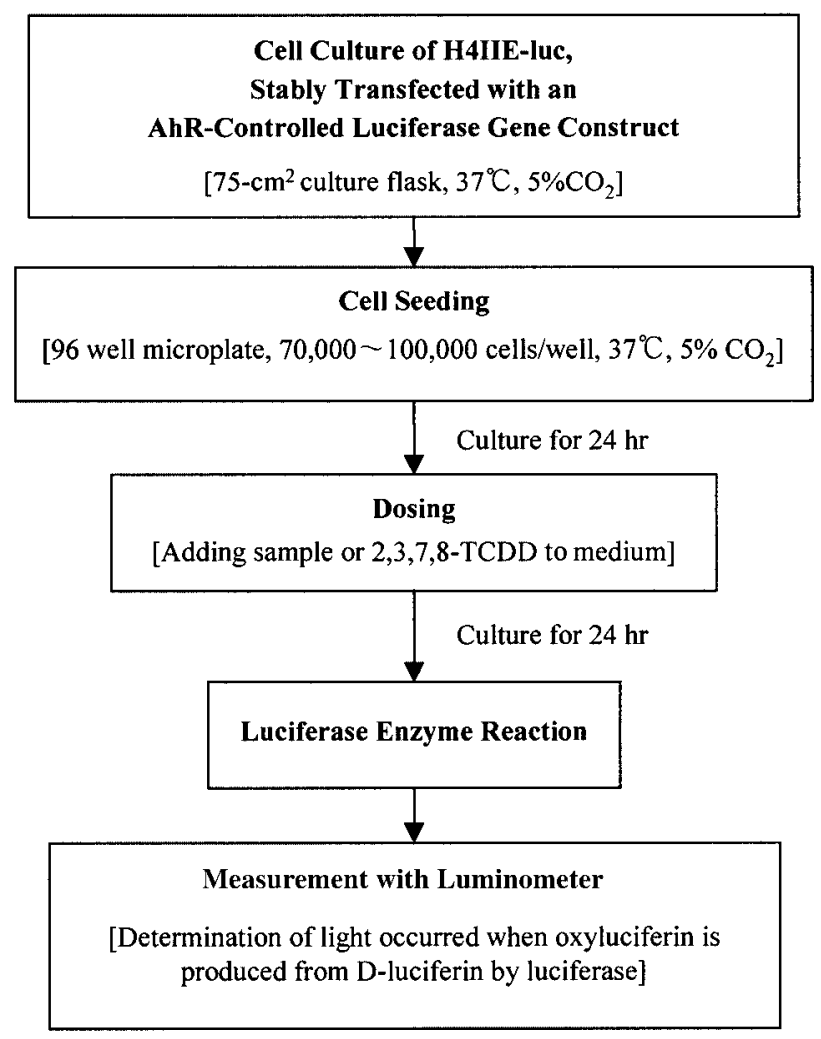

Fig. 1. Flowchart of the CALUX bioassay.

recombinant cells is less than $1 \mathrm{pM}$ TEQ $(0.06 \mathrm{pg}$ TEQ/ well) and the dose-response curve saturates at TCDD concentrations greater than $300 \mathrm{pM}$. Linear working range for the CALUX in H4IIE recombinant cells was also better than for the EROD in H4IIE wild type cells. Thus, the CALUX has been applied to human blood, human milk, cow milk, recycled paper and sediment, etc. as a promising risk assessment tool for dioxin-like compounds ${ }^{22,25-33)}$. Hereafter, "CALUX" means the DR-CALUX ${ }^{\circledR}$ (Dioxin $\underline{R}$ esponsive-Chemical Activated LUciferase eXpression) using rat hepatoma H4IIE recombinant cells and "EROD" means the micro-EROD method using rat hepatoma H4IIE $\mathrm{C} 3 / \mathrm{T}$ cell line in this paper.

The assay procedure of CALUX bioassay conducted in our institute is shown in Fig. 1. The cells were plated in plastic 96 -well plates in $0.1 \mathrm{ml} \alpha$-Minimal Essential Medium supplemented with $10 \%$ Fetal Bovine Serum per well. Following 24-hour incubation, the cells with at least $95 \%$ confluency were dosed by adding $0.1 \mathrm{ml}$ of the above medium supplemented with the chemical or extract to be tested dissolved in DMSO (0.4\%). Basically after 24-hour treatment, the dose medium was removed and the exposed wells were filled with $0.1 \mathrm{ml}$ phosphate buffer solution (PBS) 
Table 1. EROD \& CALUX activities of PCDDs/DFs and PCBs

\begin{tabular}{|c|c|c|c|c|c|c|c|c|c|}
\hline \multirow[b]{2}{*}{ Congener } & \multicolumn{5}{|c|}{ EROD-TEF(H4IIE cells) } & \multicolumn{3}{|c|}{ CALUX-TEF (H4IIE-luc cells) } & \multirow{2}{*}{$\begin{array}{c}\text { TEF/WHO } \\
\text { (Humans/ } \\
\text { mammals }\end{array}$} \\
\hline & $\begin{array}{l}\text { Safe }^{\mathrm{a}} \& \\
\text { Sawyer }^{\mathrm{b}}\end{array}$ & Clemons $^{\mathrm{c}}$ & $\begin{array}{c}\text { Schrenk }^{\mathrm{d}} \& \\
\text { Schmitz }^{\mathrm{e}}\end{array}$ & Tillitt $^{\mathrm{f}}$ & Our Study ${ }^{\mathrm{g}}$ & Sanderson ${ }^{\mathrm{h}}$ & Bovee $^{i}$ & Our Study ${ }^{\mathrm{g}}$ & \\
\hline \multicolumn{10}{|l|}{ Dioxins } \\
\hline 2,3,7,8-TetraCDD & 1 & 1 & 1 & 1 & 1 & 1 & 1 & 1 & 1 \\
\hline $1,2,3,7,8$-PentaCDD & 0.01 & 1.1 & 0.181 & 0.42 & 0.61 & 0.79 & 0.49 & 0.54 & 1 \\
\hline $1,2,3,4,7,8-\mathrm{HexaCDD}$ & 0.045 & 0.5 & 0.184 & 0.08 & 0.14 & & & 0.30 & 0.1 \\
\hline $1,2,3,6,7,8-\mathrm{HexaCDD}$ & & 0.2 & 0.043 & 0.02 & 0.15 & & 0.068 & 0.14 & 0.1 \\
\hline 1,2,3,7,8,9-HexaCDD & & & 0.061 & 0.03 & 0.049 & & & 0.066 & 0.1 \\
\hline 1,2,3,4,6,7,8-HeptaCDD & & 0.1 & 0.047 & 0.02 & 0.034 & & & 0.046 & 0.01 \\
\hline OctaCDD & $3 \times 10^{-4}$ & & $3.5 \times 10^{-4}$ & $5 \times 10^{-4}$ & & & & $4.7 \times 10^{-4}$ & 0.0001 \\
\hline \multicolumn{10}{|l|}{ Furans } \\
\hline 2,3,7,8-TetraCDF & 0.09 & 0.03 & 0.4 & 0.2 & 0.24 & & & 0.32 & 0.1 \\
\hline $1,2,3,7,8-$ PentaCDF & 0.06 & 0.2 & 0.03 & 0.2 & 0.21 & & & 0.21 & 0.05 \\
\hline 2,3,4,7,8-PentaCDF & 1.38 & 0.4 & 0.6 & 1.4 & 0.39 & 0.69 & 0.34 & 0.50 & 0.5 \\
\hline $1,2,3,4,7,8-\mathrm{HexaCDF}$ & 0.49 & 0.3 & 0.2 & 0.02 & 0.15 & & & 0.13 & 0.1 \\
\hline $1,2,3,6,7,8-\mathrm{HexaCDF}$ & 0.148 & & 0.06 & 0.06 & 0.046 & & & 0.039 & 0.1 \\
\hline 1,2,3,7,8,9-HexaCDF & & & & & 0.12 & & & 0.11 & 0.1 \\
\hline $2,3,4,6,7,8-\mathrm{HexaCDF}$ & 0.03 & & 0.1 & 0.3 & 0.11 & & & 0.18 & 0.1 \\
\hline $1,2,3,4,6,7,8$-HeptaCDF & & & & 0.3 & 0.018 & & & 0.029 & 0.01 \\
\hline $1,2,3,4,7,8,9$-HeptaCDF & & & & 0.02 & 0.021 & & & 0.041 & 0.01 \\
\hline OctaCDF & & & & & & & & 0.0065 & 0.0001 \\
\hline \multicolumn{10}{|l|}{ Non-ortho PCBs } \\
\hline $3,3^{\prime}, 4,4^{\prime}-$ TetraCB $(77)^{\mathrm{k}}$ & $9 \times 10^{-4}$ & $8 \times 10^{-4}$ & $1 \times 10^{-4}$ & $2 \times 10^{-5}$ & $4.5 \times 10^{-4}$ & $7.1 \times 10^{-4}$ & & 0.0013 & 0.0001 \\
\hline $3,4,4^{\prime}, 5$-TetraCB $(81)$ & $4 \times 10^{-5}$ & 0.007 & & 0.002 & & 0.0027 & & 0.0042 & 0.0001 \\
\hline $3,3^{\prime}, 4,4^{\prime}, 5$-PentaCB (126) & 0.32 & 0.1 & 0.2 & 0.02 & 0.046 & 0.017 & 0.065 & 0.067 & 0.1 \\
\hline 3,3',4,4',5,5'-НеxaCB (169) & 0.003 & 0.001 & 0.003 & $5 \times 10^{-4}$ & 0.0022 & $5.5 \times 10^{-4}$ & 0.0015 & 0.0034 & 0.01 \\
\hline \multicolumn{10}{|l|}{ Mono-ortho PCBs } \\
\hline 2,3,3',4,4'-PentaCB (105) & 0.0015 & $2.5 \times 10^{-5}$ & $1 \times 10^{-5}$ & $8 \times 10^{-6}$ & $9.8 \times 10^{-6}$ & & $2 \times 10^{-6}$ & $1.2 \times 10^{-5}$ & 0.0001 \\
\hline 2,3,4,4',5-PentaCB (114) & $3 \times 10^{-4}$ & & $7 \times 10^{-5}$ & $<1 \times 10^{-6}$ & $3.2 \times 10^{-5}$ & & & $4.8 \times 10^{-5}$ & 0.0005 \\
\hline 2,3',4,4',5-PentaCB (118) & $2 \times 10^{-5}$ & $1 \times 10^{-5}$ & $4 \times 10^{-6}$ & $4 \times 10^{-7}$ & $1.0 \times 10^{-5}$ & & $4.9 \times 10^{-6}$ & & 0.0001 \\
\hline $2^{\prime}, 3,4,4^{\prime}, 5$-PentaCB (123) & $1 \times 10^{-4}$ & & $1 \times 10^{-4}$ & $1 \times 10^{-5}$ & $1.4 \times 10^{-5}$ & & & $2.4 \times 10^{-5}$ & 0.0001 \\
\hline $2,3,3^{\prime}, 4,4^{\prime}, 5-$-НехаСВ (156) & $2 \times 10^{-4}$ & $5 \times 10^{-5}$ & $6 \times 10^{-5}$ & $6 \times 10^{-5}$ & $9.9 \times 10^{-5}$ & & $3.8 \times 10^{-5}$ & $2.1 \times 10^{-4}$ & 0.0005 \\
\hline $2,3,3^{\prime}, 4,4^{\prime}, 5^{\prime}-$-НехаСВ (157) & $2 \times 10^{-5}$ & & $5 \times 10^{-5}$ & $2 \times 10^{-5}$ & $4.2 \times 10^{-5}$ & & & $8.0 \times 10^{-5}$ & 0.0005 \\
\hline $2,3^{\prime}, 4,4^{\prime}, 5,5^{\prime}-$ HexaCB (167) & $9 \times 10^{-6}$ & & $8 \times 10^{-6}$ & $9 \times 10^{-6}$ & & & & $8.2 \times 10^{-6}$ & 0.00001 \\
\hline \multicolumn{3}{|c|}{$2,3,3^{\prime}, 4,4^{\prime}, 5,5^{\prime}-$ HeptaCB (189) } & $<1 \times 10^{-6}$ & $1 \times 10^{-5}$ & & & & $6.7 \times 10^{-6}$ & 0.0001 \\
\hline
\end{tabular}

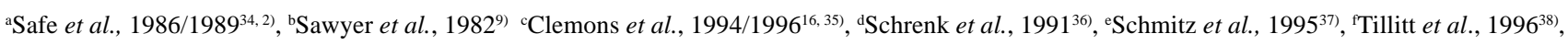

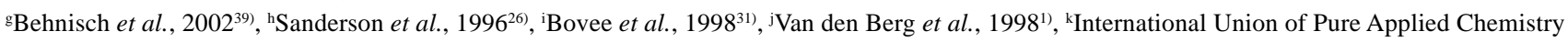
number.

containing $1 \mathrm{mM}$ calcium and magnesium ions. PBS was renewed and $0.1 \mathrm{ml}$ luclite assay substrate (PerkinElmer) was added per well. 30 minutes after the addition of assay substrate, luciferase activity was measured by a luminometer for 10 seconds per well. CALUX assay procedure itself requires 3 days.

CALUX-TEF values expressing AhR-ligand activity for single compounds were calculated by comparing the $\mathrm{EC}_{50}$ values of 2,3,7,8-TCDD and the tested chemical. The standard curve was fitted using a cumulative fit function.
CALUX-TEQ values for the extracted samples were obtained from their dilutions so that their luciferase activities were in the reproducible lower part of the linear range corresponding to $1-4 \mathrm{pM}$ in TCDD.

The dioxin-like potency of a single compound is expressed as EROD- or CALUX- TEF (toxicity equivalent factor), that is relative potency (REP) to TCDD in terms of EC50. The reported EROD- and CALUX-TEF values for PCDD/Fs and Co-PCBs are shown in Table 1, 2, 9, 16, 26, 34-39). EROD- or CALUX- TEFs were close to WHO-TEFs for PCDD/Fs and 


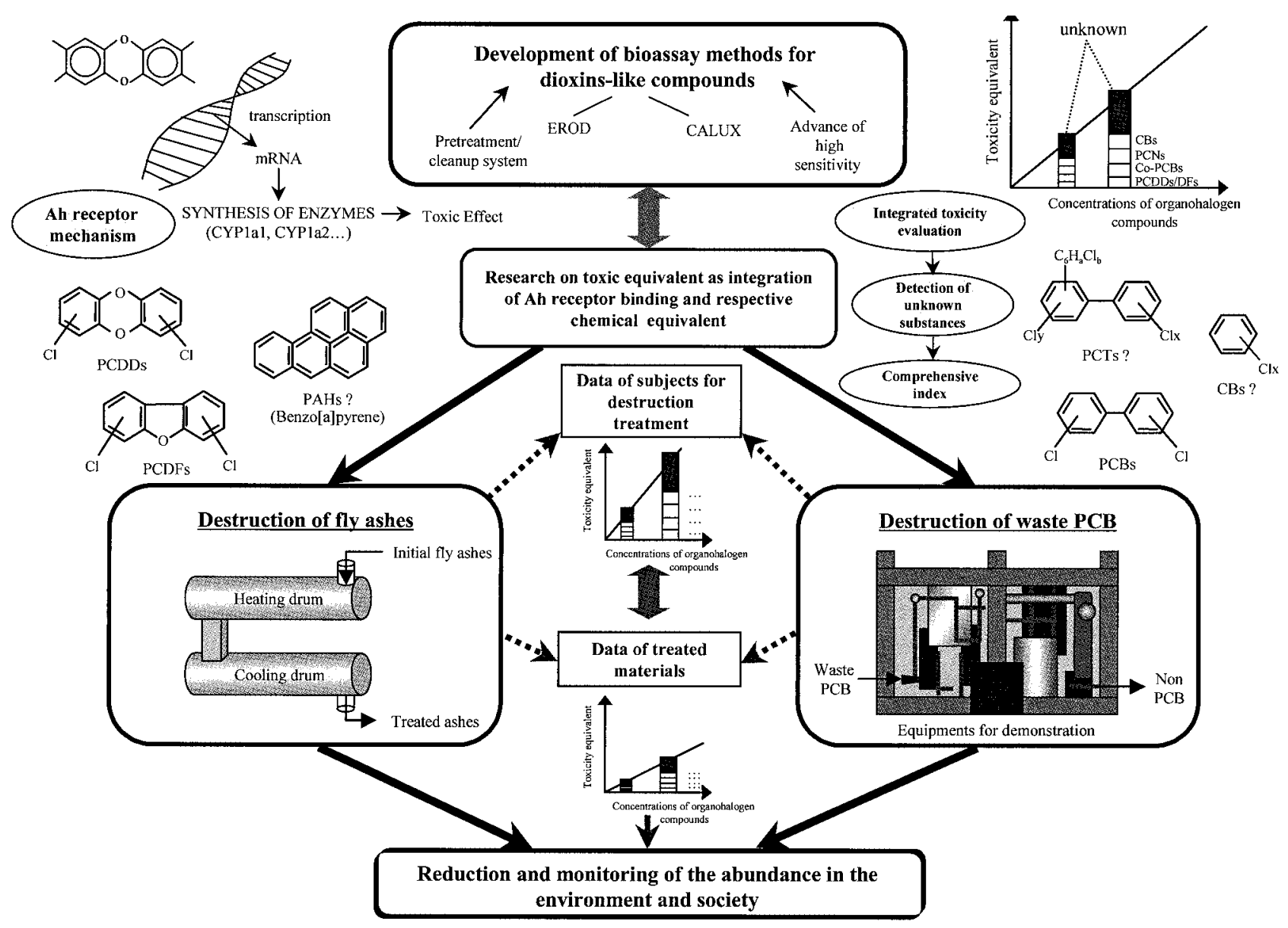

Fig. 2. Project overview of "destruction processes of dioxins/PCB and their bioassay monitoring”.

the ratio between bioassay-TEF and WHO-TEF were 0.45 with a few exceptions. Co-PCB congeners showed comparatively lower EROD- or CALUX-TEFs than expected based on the WHO-TEF values (the ratio between bioassayTEF and WHO-TEF values were 0.01-0.7), while bioassayTEF for PCB \#77 showed one order of magnitude higher than the WHO-TEF value. Our result shows a good agreement between bioassay-TEF values obtained by EROD and CALUX indicating that these two bioassays may have similar response to PCDD/Fs and Co-PCBs .

\section{Research Project on Bio-monitoring for Destruction Processes of Dioxin-like Compounds}

The authors have put forward the project research "development of dioxin/PCB destruction process and their bioassay monitoring" supported in 2000-2003 by a Grantin-aid for the Development of Innovative Technologies from the Ministry of Education, Culture, Sports, Science and Technology of Japan. Research framework comprises of three following themes as shown in Fig. 2:

-Development of bioassay methods including suitable sample pre-treatment for dioxin-like compounds

-Application of bioassay to the monitoring during destruction process of fly ashes from municipal solid waste incineration

-Analysis of PCB destruction mechanism and application of bioassay to the monitoring during chemical destruction processes of waste PCBs

In this research, EROD and CALUX methods have been positively applied to the monitoring of destruction process of wastes such as fly ashes and PCB oil on which we have little toxicological information on their behavior during the process. Monitoring of such wastes containing PCDD/Fs and Co-PCBs and their treated byproducts and assessing their risk to the environment or human health by looking at individual compounds are not feasible. Our objectives for 

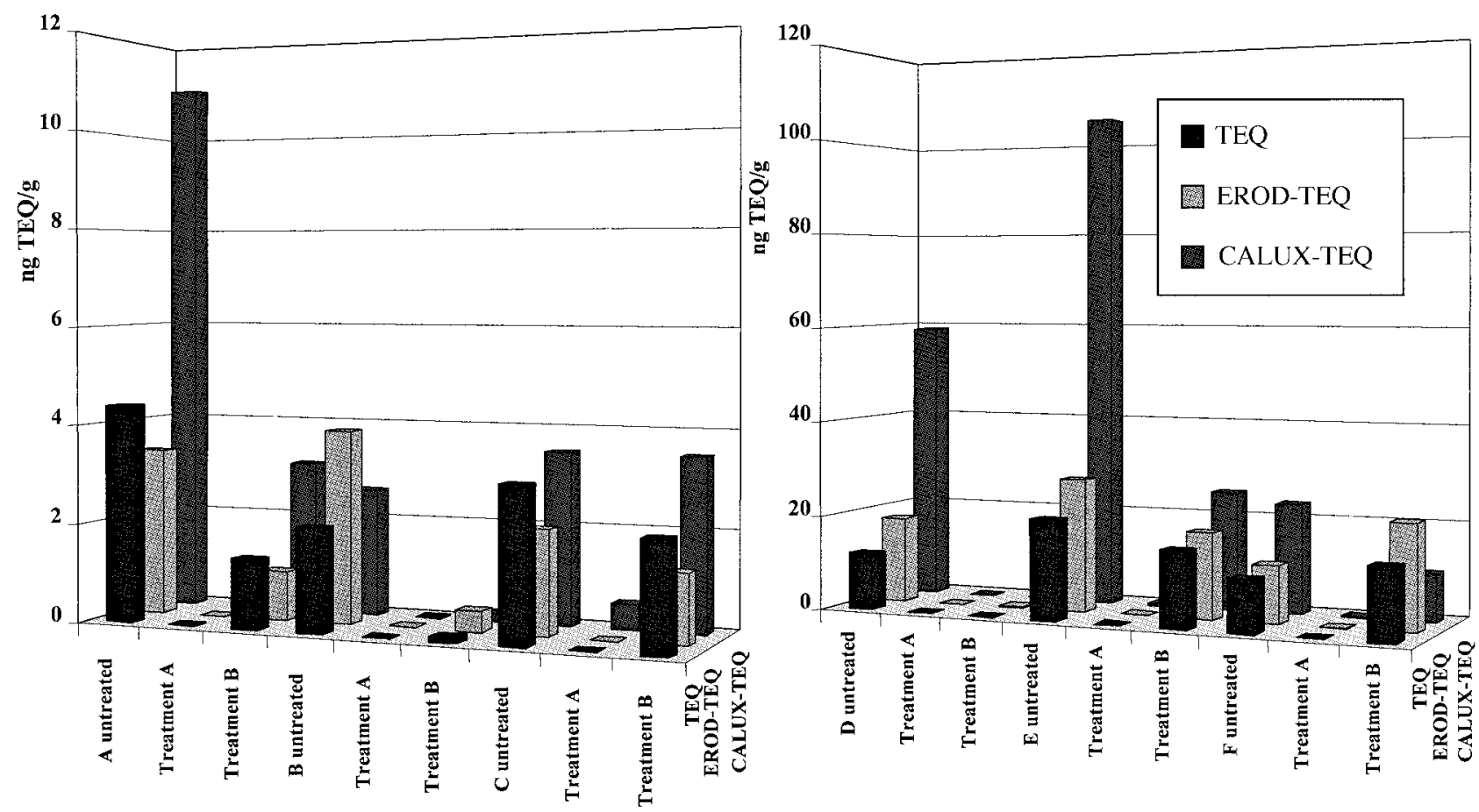

Fig. 3. Chemical-TEQ and bioassay-TEQ of several untreated and treated ashes.

the practical use of bioassays are the two points below; -From a toxicology-directed viewpoint, EROD and CALUX bioassays where dioxin-like effects are directly estimated can provide important information on the predicted overall dioxin-like potency of the complex mixture of samples. Those bioassays can be more useful if combined with instrumental analytical approaches in terms with Toxicity Identification and Evaluation (TIE). In conducting TIE approaches, bioassays are associated with sample fractionation and instrumental analysis to elucidate the compounds contributed to dioxin-like toxicity in the sample. -From a standpoint based on the necessity of rapid screening, bioassays can be a promising tool. If a certain correlation can be found between bioassay index (e.g., bioassay-TEQ) and chemical concentrations (e.g., I-TEQ, WHO-TEQ) in the tested sample matrices, rapid and costless bioassay can provide significant information or may be possibly replaced/ complemented with instrumental analysis for screening samples with significant levels of dioxin-like compounds. The latest findings on this project research were abstracted below.

\section{Bioassay Application for Municipal Solid Waste Residues}

To investigate the dechlorination of fly ashes during a low temperature treatment under oxygen deficiency conditions (thermo-catalytic treatment or Hagenmaier process) six fly ashes from six different incineration plants were treated in a laboratory experiment $\left(300^{\circ} \mathrm{C}, 30 \mathrm{~min}\right)$ or in an actual plant $\left(400^{\circ} \mathrm{C}, 120 \mathrm{~min}\right)$. The aim of this study was to confirm the decrease of the I-TEQ (international toxicity equivalency of PCDD/Fs and Co-PCBs) and for the first time also the decrease in the sum of dioxin-like toxicity (bioassay-TEQ) measured by EROD and CALUX ${ }^{40)}$.

I-TEQ and bioassay-TEQ values in untreated and treated fly ashes of municipal solid waste incineration were obtained as shown in Fig. 3. The here described combination of bioassay and chemical analysis resulted in I-TEQ, ERODand CALUX-TEQ values of untreated fly ashes for plants A-D in a range between 2.1-12 ng-I-TEQ/g, 2.1-18 ngEROD-TEQ/g and 2.6-59 ng-CALUX-TEQ/g, respectively. These values are in the same range as the values previously reported ${ }^{41}$. Bioassay-TEQ values for the untreated fly ashes $(n=6)$ were on average maximal 3-times higher than I-TEQs, indicating the importance of PCDD/Fs for the sum of dioxinlike toxicity. Analysis of six untreated fly ashes revealed excellent correlation between bioassay-TEQ and I-TEQ (EROD: $\mathrm{r}^{2}=0.94$; CALUX: $\mathrm{r}^{2}=0.92$ ). Including also treated fly ash samples (total sum of samples: $n=18$ ), the correlation coefficient increases in case of the EROD bioassay $\left(r^{2}=0.96\right)$, while decreases in case of the CALUX assay $\left(r^{2}=0.72\right)$. This 
could maybe explained due to the different kinetics (CALUX: $24 \mathrm{~h}$ versus EROD: $72 \mathrm{~h}$ ) and the therefore different metabolic capacities of the cells. Similar bioassay-TEQ/ChemicalTEQ ratio values were already reported for studies measuring ash samples from various sources using cell based bioassays such as the H4IIE-EROD ${ }^{41-44)}$ or CALUX using mouse hepatoma cells ${ }^{45}$ (for review see literature ${ }^{46,41}$ ).

The I-TEQ/EROD-TEQ/CALUX-TEQ values of four untreated fly ash could be decreased in the plants from a mean value of 5.4 (chemical analysis)/6.9 (EROD)/19 (CALUX) ng TEQ/g to finally a level of 0.02/0.02/0.52 ng $\mathrm{TEQ} / \mathrm{g}$ at maximum after the dechlorination treatment. This resulted in treatment efficiencies (TE \%) based on I-TEQs, EROD-and CALUX-TEQ values for ashes treated in plant $\mathrm{A}, \mathrm{B}$ and $\mathrm{D}$ of more than $99 \%$. It could be shown that the dechlorination/hydrogenation (Hagenmaier process) treatment of fly ashes reduces I-TEQ and bioassay-TEQ values of the untreated sample up to $99 \%$. Comparing the I-TEQ and bioassay-TEQ levels from the tested six fly ashes indicated only a small amount of unknown dioxin-like compounds (such as brominated dioxin-like compounds) occurred.

The findings so far on the fly ash thermo-catalytic treatment have confirmed that concentrations of PCDD/Fs decreased, but this doesn't mean that the characterization of final products or the decomposition mechanism of fly ashes have been confirmed. Therefore, the findings have not given proper answers to the concerns whether other uneasy byproducts could be formed by the dechlorination, even if the concentration of PCDD/Fs is certainly declined. New findings to answer the questions are as follows, 1) the decomposition rate of bioassay-TEQ is obtained to be almost equivalent to the PCDD/Fs by chemical analysis. 2) while I-TEQ concentration by low temperature treatment under the condition of $400^{\circ} \mathrm{C}, 120$ minutes is $0.01-0.1 \mathrm{ng} \mathrm{TEQ} / \mathrm{g}$, it is confirmed that bioassay-TEQ is $0.02-0.5 \mathrm{ng} \mathrm{TEQ} / \mathrm{g}$. 3) Although the bioassay-TEQ/chemical-TEQ ratio value was about a few times, there is no striking difference of the proportion before and after the treatment. Consequently, it is proved that a large amount of $\mathrm{Ah}$ receptor agonists except PCDD/Fs cannot be formed as by-products after the dechlorination of fly ashes.

Similar bioassay-TEQ/I-TEQ ratios between treated and untreated ashes indicates that equal amounts of dioxin-like compounds known as PCDD/Fs and coplanar PCB and unknown dioxin-like compounds are decontaminated in the here described dechlorination/hydrogenation process. Both here used rat hepatoma H4IIE cell based bioassays are available for monitoring the reduction of overall dioxin-like toxicity through the here described decomposition performance.

\section{Chemical Destruction Methods of Waste PCBs and their Integrated Monitoring}

Bioassay analysis can be also a promising tool to measure the reduction of PCBs and other undesirable by-products such as PCDD/Fs during chemical destruction processes. The described study here focuses on mineral insulating oil and capacitor oil containing PCBs and their chemically treated samples ${ }^{47}$.

In conducting this research, mineral insulating oil contains quite high amounts (several \% wt) of polyaromatic hydrocarbons (PAHs) originated from mineral oil. The AhR agonist activity of PAHs might be overwhelming and could lead to a misinterpretation of the activity of PCBs. Therefore, clean-up procedures for separating PCBs from mineral oil matrix were validated and evaluated. Silica gel/sulfuric acid (44\%) reflux treatment was established and used as a

Table 2. CALUX-TEQ values $(\mu \mathrm{g} / \mathrm{kg}$ ) and induction strength for actual waste PCB (treated) samples (results for each fraction of four cleanup methods)

\begin{tabular}{|c|c|c|c|c|c|c|}
\hline \multirow{2}{*}{$\begin{array}{l}\text { (Treated) waste PCB samples } \\
\text { Pretreatment type }\end{array}$} & \multicolumn{2}{|c|}{$\mathrm{Pd} / \mathrm{C}$ treated PCB-1 } & \multicolumn{2}{|c|}{$\mathrm{Pd} / \mathrm{C}$ treated $\mathrm{PCB}-2$} & \multicolumn{2}{|c|}{ PCB insulation oil } \\
\hline & Bio-TEQ & Induction & Bio-TEQ & Induction & Bio-TEQ & Induction \\
\hline Method A (DMSO/n-hexane extraction) & 0.78 & 39 & 0.35 & 27 & 2,200 & 62 \\
\hline Method B (A+ silica gel- $\mathrm{H}_{2} \mathrm{SO}_{4}(22 \%)$ reflux $)$ & 0.36 & 14 & 0.45 & 25 & 3,100 & 60 \\
\hline Method C (A+ silica gel- $\mathrm{H}_{2} \mathrm{SO}_{4}(44 \%)$ reflux) & NM & NM & NM & NM & 11 & 49 \\
\hline Method D (C+ activated carbon dispersed silica gel $)$ & $<0.1$ & - & 0.31 & 42 & 1.0 & 77 \\
\hline PCB content $(\mu \mathrm{g} / \mathrm{kg})$ & \multicolumn{2}{|c|}{$<100$} & \multicolumn{2}{|c|}{5,200} & \multicolumn{2}{|c|}{6,900} \\
\hline I-TEQ ( $\mu \mathrm{g}-\mathrm{TEQ} / \mathrm{kg})$ & \multicolumn{2}{|c|}{0.00072} & \multicolumn{2}{|c|}{0.11} & \multicolumn{2}{|c|}{0.30} \\
\hline Bio-TEQ (method D)/I-TEQ & \multicolumn{2}{|c|}{ - } & \multicolumn{2}{|c|}{2.8} & \multicolumn{2}{|c|}{3.3} \\
\hline
\end{tabular}

Key: NM, not measured; induction, induction strength (\% TCDD max). 
complete removal method of PAHs in samples prior to CALUX. PCBs themselves are AhR agonists and antagonists in complex mixtures. 2-4 ortho PCBs have been reported to act as antagonists which mask the AhR binding activity of agonists of $0-1$ ortho PCBs ${ }^{48-51}$. "Agonistic" $0-1$ ortho planar PCBs and PCDD/DFs have been fractionated as an attempt by using activated carbon dispersed silica gel column. Then the obtained CALUX results with/without the carbon column treatment were compared.

To ascertain the usefulness of the proposed clean-up method, fractions of the three actual PCB (treated) wastes were sampled at each level of clean-up procedures, replaced with DMSO and assayed using CALUX (Table 2). Overestimation (>1,000 fold of interference) of bioassayTEQ for Pd/C (Palladium/carbon catalyst) treated PCB capacitor oil-1 and PCB insulating oil samples (method A fractions) was remarkably improved by completing the proposed pre-treatment (method D fractions). Finally, the ratio between bioassay-TEQ and I-TEQ values for $\mathrm{Pd} / \mathrm{C}$ treated PCB capacitor oil-2 and PCB insulating oil became 2.8 and 3.3, respectively. Bioassay-TEQ value for $\mathrm{Pd} / \mathrm{C}$ treated PCB capacitor oil-1 became under the determination limit.

To check the assay sensitivity to mineral oil samples, PCBcontaining mineral oil of various concentrations from 0.5 $\mathrm{ppm}$ to $50 \mathrm{ppm}$ in total PCBs was prepared by diluting Kanechlor-400 based capacitor oil diluted with the oil. Fractions obtained by both of the reflux pretreatment and additional carbon column fractionation were tested by the CALUX.The CALUX data showed good agreement with ITEQ values for all the tested range of PCB samples in both fractions of reflux and additional carbon column treatment. The ratio of CALUX-TEQ divided by I-TEQ was all in the range of $1-3$. CALUX can theoretically quantify the TEQ up to $0.01 \mathrm{ppb}(10 \mathrm{pg}-\mathrm{TEQ} / \mathrm{g})$ level on the adopted scale of sample clean-up.

\section{Open Questions on Future Biomonitoring Design}

The use of the CALUX system here described for the detection of Ah receptor agonist has many advantages. It is easier, more reliable, less time consuming, and fewer imhibition effects has been reported. Therefore, this bioassay could be a valuable new tool for rapid screening of complex environmental pollutants and waste management samples. The wide possibility of application makes this tool very useful for biomonitoring studies as well as screening of industrial chemicals or environmental control processes. But, in the future, this system should also have several quality criteria like the chemical analysis, which still has to be evaluated and applied on round robin studies ${ }^{52,53)}$. There is an urgent need to evaluate which clean-up should be used with or without non-dioxin-like compounds such as PAHs and which compounds should be tested for their dioxin-like potency. In the future, it would be desirable to lessen the necessary amounts of samples and simplify the process of pretreatment within a range which quantitative determination can be maintained. In addition, false negative ratio, which means true value by chemical analysis shows control value and over whereas bioassay value indicates less than control value, is required to be minimized. The applicable uses of bioassay method can be expanded not only to grasp the actual toxic overviews of industrial chemicals and environmental pollutions, but as this research mentioned, to manage processes such as observing toxicity change and confirming the destruction status. While appropriate validations are conducted continuously, it is expected to be applied practically.

\section{Acknowledgements}

The presented project was financially supported between 2000 and 2003 by a Grant-in-aid for the Development of Innovative Technologies from the Ministry of Education, Culture, Sports, Science, and Technology from Japan. The authors wish to thank Dr. P. Behnisch from SGS (Germany) and Prof. A. Brouwer of BioDetection Systems (The Netherlands) for their continued support for the development of the DR-CALUX ${ }^{\circledR}$ system and its application; and Dr. K. Hosoe of Kaneka Corporation and Mr. K. Shiozaki of Kaneka Techno Research for excellent technical assistance.

\section{References}

1) Van den Berg, M, Birnbaum L, Bosveld ATC, Brunström B, Cook P, Feeley M, Giesy JP, Hanberg A, Hasegawa R, Kennedy SW, Kubiak T, Larsen JC, van Leeuwen FX R, Liem AKD, Nolt C, Peterson RE, Poellinger L, Safe S, Schrenk D, Tillitt D, Tysklind M, Younes M, Waern F, Zacharewski T (1998) Toxic equivalency factors (TEFs) for PCBs, PCDDs, PCDFs for humans and wildlife. Environ Health Perspect 106, 775-91.

2) Safe $S$, Mason G, Sawyer T, Zacharewski T, Harris M, Yao C, Keys B, Farrell K, Holcomb M, Davis D, Safe L, Piskorska-Pliszczynska J, Leece B, Denomme MA, Hutzinger O, Thoma H, Chittim B, Madge J (1989) Development and validation of in vitro induction assays 
for toxic halogenated aromatic mixtures: A review. Toxicol Ind Health 5, 757-75.

3) Nagao T, Neubert D, Löser E (1990) Comparative studies on the induction of ethoxyresorufin- $O$ deethylase by 2,3,7,8-TCDD and 2,3,7,8-TBrDD. Chemosphere 20, 1189-92.

4) Schulz-Schalge T, Koch E, Schwind K-H, Hutzinger O, Neubert D (1991) Inductive potency of TCDD, TBDD and three 2,3,7,8-mixed-halogenated dioxins in liver microsomes of male rats. Enzyme kinetic considerations. Chemosphere 23, 1925-31.

5) Andersson PL, van der Burght ASAM, van den Berg M, Tysklind M (2000) Multivariate modeling of polychlorinated biphenyl-induced CYP1A activity in hepatocytes from three different species: ranking scales and species differences. Environ Toxicol Chem 19, 1454-63.

6) Kirby MF, Neall P, Tylor T (1999) EROD activity measured in flatfish from the area of the Sea Empress oil spill. Chemosphere 38, 2929-49.

7) Willett KL, McDonald SJ, Steinberg MA, Beatty KB, Kennicutt MC, Safe SH (1997) Biomarker sensitivity for polynuclear aromatic hydrocarbon contamination in two marine fish species collected in Galveston bay, Texas. Environ Toxicol Chem 16, 1472-9.

8) Fragoso NM, Parrott JL, Hahn ME, Hodson PV (1998) Chronic retene exposure causes sustained induction of CYP1A activity and protein in rainbow trout (Oncorhynchus mykiss). Environ Toxicol Chem 17, 2347-53.

9) Sawyer T, Safe S (1982) PCB isomers and congeners: Induction of aryl hydrocarbon hydroxylase and ethoxyresorufin- $O$-deethylase enzyme activities in rat hepatoma cells. Toxicol Lett 13, 87-94.

10) Zacharewski T, Safe L, Safe S, Chittim B, DeVault D, Wiberg K, Bergqvist P-A, Rappe C (1989) Comparative analysis of polychlorinated dibenzo- $p$-dioxin and dibenzofuran congeners in Great Lake fish extracts by gas chromatography-mass spectrometry and in vitro enzyme induction activities. Environ Sci Technol 23, 730-5.

11) Zacharewski $T$, Harris $M$, Safe $S$ (1989) Induction of cytochrome $\mathrm{P} 450$-dependent monooxygenase activities in rat hepatoma H-4-IIE cells in culture by 2,3,7,8tetrachlorodibenzo- $p$-dioxin and related compounds: Mechanistic studies using radiolabeled congeners. Arch Biochem Biophys 272, 344-55.

12) Tillitt DE, Giesy JP (1991) Characterization of the H4IIE rat hepatoma cell bioassay as a tool for assessing toxic potency of planar halogenated hydrocarbons in environmental samples. Environ Sci Technol 25, 8792.

13) Kopponen P, Törrönen R, Tarhanen J, Ruuskanen J, Kärenlampi S (1991) Cytochrome P4501A1 induction in mouse hepatoma cell culture as an indicator of polycyclic organic compounds in fly ash. Chemosphere 22, 895-904.

14) Lipp H-P, Schrenk D, Wiesmüller T, Hagenmaier H, Bock KW (1992) Assessment of biological activities of mixtures of polychlorinated dibenzo- $p$-dioxins (PCDDs) and their constituents in human HepG2 cells. Arch Toxicol 66, 220-3.

15) De Haan LH, Simons JW, Bos AT Aarts JM, Denison MS, Brouwer A (1994) Inhibition of intracellular communication by 2,3,7,8-tetrachlorodibenzo- $p$-dioxin and dioxin-like PCBs in mouse hepatoma cells (Hepa1c1c7): Involvement of the Ah receptor. Toxicol Appl Pharmacol 129, 283-93.

16) Clemons JH, van den Heuvel MR, Stegeman JJ, Dixon DG, Bols NC (1994) Comparison of toxic equivalent factors for selected dioxin and furan congeners derived using fish and mammalian liver cell lines. Can J Fish Aquat Sci 51, 1577-84.

17) Dubois M, De Waziers I, Thome JP, Kremers P (1996) P450 induction by Aroclor 1254 and 3,3',4,4'tetrachlorobiphenyl in cultured hepatocytes from rat, quail and man: Interspecies comparison. Comp Biochem Physiol 113, 51-9.

18) Villeneuve DL, Crunkilton RL, DeVita WM (1997) Aryl hydrocarbon receptor-mediated toxic potency of dissolved lipophilic organic contamination collected from Lincoln creek, Milwaukee, Wisconsin, USA, to PLHC-1 (Poeciliopsia lucida) fish hepatoma cells. Environ Toxicol Chem 16, 977-84.

19) Engwall M, Brunström B, NäF C, Hjelm K (1999) Levels of dioxin-like compounds in sewage sludge determined with a bioassay based on EROD induction in chicken embryo liver cultures. Chemosphere 38, 2327-43.

20) Aarts JM, Denison MS, Cox MA, Schalk MAC, Garrison PM, Tullis K, de Haan LHJ, Brouwer A (1995) Species-specific antagonism of Ah receptor action by 2,2',5,5' -tetrachloro- and 2,2',3,3',4,4' hexachlorobiphenyl. Eur J Pharmacol Environ Toxicol 293, 463-74.

21) Hoogenboom RLAP, Hamers ARM (1995) Effects of oxfendazole on the Ah receptor-mediated induction of ethoxyresorufin- $O$-deethylase and luciferase activity 
by 2,3,7,8-tetrachlorodibenzo- $p$-dioxin in Hepa-1c1c7 and H4IIE cell-lines. Organohalogen Compounds 25, 53-6.

22) Murk AJ, Legler J, Denison MS, Giesy JP, van de Guchte C, Brouwer A (1996) Chemical-activated luciferase gene expression (CALUX): A novel in vitro bioassay for Ah receptor active compounds in sediments and pore water. Fund Appl Toxicol 33, 149-60.

23) Denison MS, El-Fouly MH, Aarts JM, Brouwer A, Richter C, Giesy JP (1993) Production of novel recombinant cell line bioassay systems for detection of 2,3,7,8-tetrachlorodibenzo- $p$-dioxin-like chemicals. Organohalogen Compounds 13, 365-8.

24) Aarts JM, Denison MS, De Haan LHJ, Schalk JAC, Cox MA, Brouwer A (1993) Ah receptor-mediated luciferase expression: a tool for monitoring dioxin-like toxicity. Organohalogen Compounds 13, 361-4.

25) Garrison PM, Tullis K, Aarts JM, Brouwer A, Giesy JP, Denison MS (1996) Species-specific recombinant cell lines as bioassay systems for the detection of 2,3,7,8tetrachlorodibenzo-p-dioxin-like chemicals. Fund Appl Toxicol 30, 194-203.

26) Sanderson JT, Aarts JM, Brouwer A, Froese KL, Denison MS, Giesy JP (1996) Comparison of Ah receptor-mediated luciferase and ethoxyresorufin- $O$ deethylase induction in H4IIE cells: implications for their use as bioanalytical tools for the detection of polyhalogenated aromatic hydrocarbons. Toxicol Appl Pharmacol 137, 316-25.

27) Denison MS, Rogers WJ, Fair M, Ziccardi M, Clark G, Murk AJ, Brouwer A (1996) Application of the CALUX bioassay systems for the detection of dioxinlike chemicals (Ah receptor ligands) in whole serum samples and in extracts from commercial and consumer products. Organohalogen Compounds 27, 280-4.

28) Aarts JM, Cenijn PH, Blankvoort BMG, Murk AJ, Brouwer A, Bovee TFH, Traag WA, Hoogenboom LAP, Patandin S, Weisglas-Kuperus N, Sauer PJJ, Denison MS (1996) Application of the chemical-activated luciferase expression (CALUX) bioassay for quantification of dioxin-like compounds in small samples of human milk and blood plasma. Organohalogen Compounds 27, 285-90.

29) Murk AJ, Jonas A, Brouwer A, Leonards PEG, Denison MS (1996) Application of the CALUX (chemical activated luciferase gene expression) assay for measuring TCDD-equivalents in sediment, pore water and blood plasma samples. Organohalogen Compounds 27, 291-6.
30) Murk AJ, Leonards PEG, Bulder AS, Jonas AS, Rozemeijer MJC, Denison MS, Koeman JH, Brouwer A (1997) The CALUX (chemical-activated luciferase expression) assay adapted and validated for measuring TCDD equivalents in blood plasma. Environ Toxicol Chem 16, 1583-9.

31) Bovee TFH, Hoogenboom LAP, Hamers ARM, Traag WA, Zuidema T, Aarts JM, Brouwer A, Kuiper HA (1998) Validation and use of the CALUX-bioassay for the determination of dioxins and PCBs in bovine milk. Food Add Contam 15, 863-75.

32) Schecter AJ, Sheu SU, Birnbaum LS, DeVito MJ, Denison MS, Päpke O (1999) A comparison and discussion of two differing methods of measuring dioxinlike compounds Gas chromatography-mass spectrometry and the CALUX bioassay-Implications for health studies. Organohalogen Compounds 40, 247-50.

33) Khim JS, Villeneuve DL, Kannan K, Lee KT, Snyder SA, Koh C-H, Giesy JP (1999) Alkylphenols, polycyclic aromatic hydrocarbons, and organochlorines in sediment from Lake Shihwa, Korea: Instrumental and bioanalytical characterization. Environ Toxicol Chem 18, 2424-32.

34) Safe SH (1986) Comparative toxicology and mechanism of action of polychlorinated dibenzo- $p$ dioxins and dibenzofurans. Annu Rev Pharmacol Toxicol 26, 371-99.

35) Clemons JH, Lee LEJ, Myers CR, Dixon DG, Bols NC (1996) Cytochrome P4501A1 induction by polychlorinated biphenyls (PCBs) in liver cell lines from rat and trout and the derivation of toxic equivalency factors. Can J Fish Aquat Sci 53, 1177-85.

36) Schrenk D, Lipp H-P, Wiesmüller T, Hagenmaier H, Bock KW (1991) Assessment of biological activities of mixtures of polychlorinated dibenzo-p-dioxins: comparison between defined mixtures and their constituents. Arch Toxicol 65, 114-8.

37) Schmitz H-J, Hagenmaier A, Hagenmaier H-P, Bock KW, Schrenk D (1995) Potency of mixtures of polychlorinated biphenyls as inducers of dioxin receptor-regulated CYP1A activity in rat hepatocytes and H4IIE cells. Toxicology 99, 47-54.

38) Tillitt DE, Gale RW, Meadows JC, Zajicek JL, Peterman PH, Heaton SN, Jones PD, Bursian SJ, Kubiak TJ, Giesy JP, Aulerich RJ (1996) Dietary exposure of mink to carp from Saginaw Bay. 3. Characterization of dietary exposure to planar halogenated hydrocarbons, dioxin equivalents, and biomagnification. Environ Sci Technol 30, 283-91. 
39) Behnisch PA, Hosoe K, Sakai S. Relative potencies (REPs) of several Ah receptor agonists measured by two cell bioassays. Environ Int (submitted)

40) Behnisch P, Hosoe K, Shiozaki K, Ozaki H, Nakamura K, Sakai S (2002) Low-temperature thermal decomposition of dioxin-like compounds in fly ash: Combination of chemical analysis with in vitro bioassays (EROD and DR-CALUX). Environ Sci Technol 36, 5211-7.

41) Behnisch P, Hosoe K, Shiozaki K, Kiryu T, Komatsu K, Schramm K-W, Sakai S (2002) Melting and incineration plants of municipal waste, Chemical and biochemical diagnosis of thermal processing samples (emission, residues). Environ Sci Pollut Res 9, 337-44.

42) Schramm K-W, Hofmaier A, Klobasa O, Kaune A, Kettrup A (1999) Biological in vitro emission control. J Anal Appl Pyrolysis 49, 199-210.

43) Schramm K-W, Klimm C, Hofmaier A, Kettrup A (2001) Dioxin-like-response and micronuclei induction of domestic and industrial emissions and materials. Chemosphere 42, 551-7.

44) Till M, Behnisch P, Hagenmaier H, Bock KW, Schrenk D (1997) Dioxinlike components in incinerator fly ash: A comparison between chemical analysis data and results from a cell culture bioassay. Environ Health Perspect 105, 1326-32.

45) Fujii Y, Matsui T, Fujino J, Nakamura M, Kitagawa H, Murata H, Okita T, Imai T (2001) Application of iron oxide catalyst to detoxify dioxins in fly ash and possibility of CALUX ${ }^{\mathrm{TM}}$ assay for saving analysis cost and time. Organohalogen Compounds 54, 211-4.

46) Behnisch PA, Hosoe K, Sakai S (2001) Combinatorial bio/chemical analysis of dioxins and dioxin-like compounds in waste recycling, feed/food, humans/ wildlife and environment. Environ Int 27, 495-519.
47) Takigami H, Hosoe K, Behnisch PA, Shiozaki K, Mizukami H, Ohno M, Sakai S (2002) Validation study for practical bio-monitoring of waste PCB samples during their destruction treatment using DR-CALUX ${ }^{\circledR}$ assay and PCB immunoassay. Organohalogen Compounds 58, 397-400.

48) Schmitz HJ, Behnisch P, Hagenmaier A, Hagenmaier H, Bock KW, Schrenk D (1996) CYP1A1-inducing potency in H4IIE cells and chemical composition of technical mixtures of polychlorinated biphenyls. Environ Toxicol Pharmacol 1, 73-9.

49) Van der Plas SA, Gibbs CM, Brouwer A (1998) Antagonistic effects of mono- and di-ortho-substituted PCBs in the EROD activity and the luciferase reporter gene assay in vitro. Organohalogen Compounds 37, 183-6.

50) Garrison PM, Tullis K, Aarts JM, Brouwer A, Giesy JP, Denison MS (1996) Species-specific recombinant cell lines as bioassay systems for the detection of 2,3,7,8TCDD-like chemicals. Fund Appl Toxicol 30, 194-203.

51) Sakai S, Behnisch PA, Hosoe K, Shiozaki K, Ohno M, Brouwer A (2001) PCB destruction by catalytic hydrodechlorination (CHD) and t-BuOK method: combinatorial bio/chemical analysis. Organohalogen Compounds 54, 293-6.

52) Behnisch P, Hosoe K, Brouwer A, Sakai S (2002) Screening of dioxin-like toxicity equivalents for various matrices with wildtype and recombinant rat hepatoma H4IIE cells. Toxicol Sci 69, 125-30.

53) Behnisch PA, Allen R, Anderson J, Brouwer A, Brown DJ, Campbell TC, Goeyens L, Harrison RO, Hoogenboom R, Van Overmeire I, Traag W, Malisch R (2001) Harmonized quality criteria for chemical and bioassays analyses of PCDDs.PCDFs in feed and food. Organohalogen Compounds 50, 59-63. 